\title{
Factors associated with unprotected sex in people who consume sexually explicit media
}

\author{
Fatores associados ao sexo sem uso de preservativos por pessoas consumidoras de mídias sexualmente explícitas
}

Factores relacionados al sexo sin uso de condones por personas consumidores de medios sexualmente explícitos

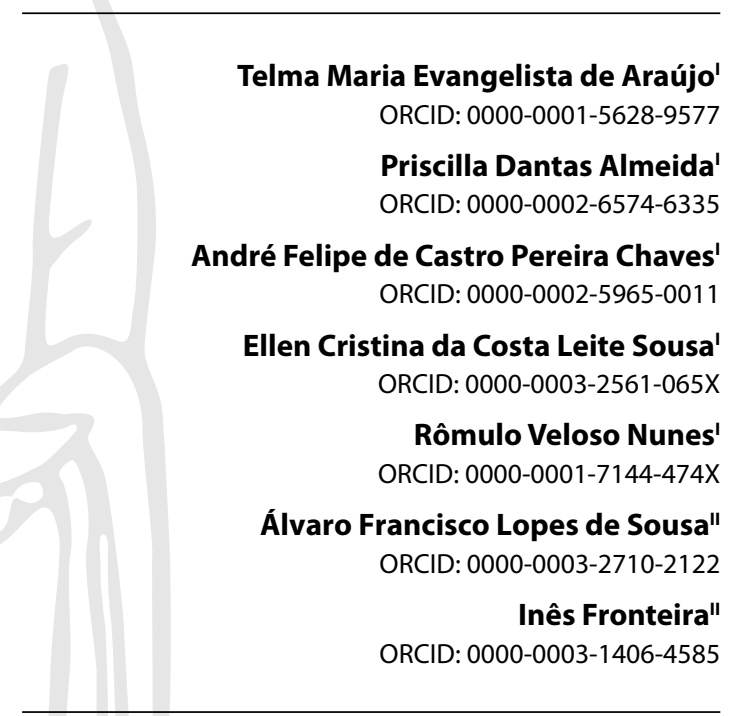

'Universidade Federal do Piauí. Teresina, Piauí, Brazil. "Universidade NOVA de Lisboa. Lisboa, Portugal.

How to cite this article: Araújo TME, Almeida PD, Chaves AFCP, Sousa ECCL, Nunes RV, Sousa AFL, et al. Factors associated with unprotected sex in people who consume sexually explicit media. Rev Bras Enferm. 2021;74(6):e20210061. https://doi.org/10.1590/0034-7167-2021-0061

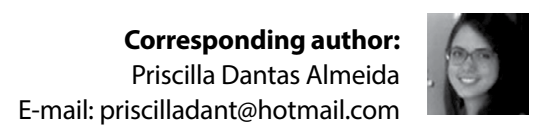

EDITOR IN CHIEF: Antonio José de Almeida Filho ASSOCIATE EDITOR: Hugo Fernandes

\section{ABSTRACT}

Objective: To analyze the factors associated with sex without the use of condoms in consumers of sexually explicit media (SEM). Methods: Cross-sectional study, with a sample of 172 participants selected and collected through social media. To assess the predictors of unprotected sexual practices, the Poisson regression model was used. Values were expressed as a robust prevalence ratio (PR) with their respective confidence intervals. Results: There was a statistically significant association between, the use of condoms and the type of scenes that the participants prefer $(p=0.03)$, the preference for films with scenes involving unprotected sex or even those that do not care about protection $(p=0.02)$, the type of pornography watched influencing sexual relations $(p=0.017)$, and the number of scenes seen per week $(p=0.05)$. Conclusions The lack of condom use was associated with the access to erotic scenes.

Descriptors: Sex; Condoms; People; Video-Audio Media; Sexual Behavior.

\section{RESUMO}

Objetivo: Analisar os fatores associados ao sexo sem uso de preservativos em consumidores de mídias sexualmente explícitas (MSEs). Métodos: Estudo transversal, com amostra de 172 participantes selecionados e coletados na ambiência virtual de mídias sociais. Para avaliar os fatores preditores da prática sexual sem uso do preservativo, utilizou-se o modelo de regressão de Poisson. Os valores foram expressos na forma de razão de prevalência (RP) robusta com seus respectivos intervalos de confiança. Resultados: Verificou-se associação estatisticamente significante do uso de preservativos com o tipo de cenas que prefere ( $p=$ $0,03)$, preferência por filmes com cenas envolvendo sexo sem proteção ou mesmo aqueles que não se importam quanto a esse cuidado $(p=0,02)$, tipo de pornografia que assiste influenciando nas suas relações sexuais $(p=0,017)$ e número de cenas vistas por semana $(p=0,05)$. Conclusões: $O$ não uso do preservativo foi associado ao acesso às cenas eróticas. Descritores: Sexo; Preservativos; Pessoas; Mídia Audiovisual; Comportamento Sexual.

\section{RESUMEN}

Objetivo: Analizar factores relacionados al sexo sin uso de preservativos en consumidores de medios sexualmente explícitos (MSEs). Métodos: Estudio transversal, con muestra de 172 participantes seleccionados y recogidos en ambiente virtual de medios sociales. Para evaluar los factores predictores de la práctica sexual sin uso del preservativo, utilizó el modelo de regresión de Poisson. Valores fueron expresos en medida de razón de prevalencia (RP) robusta con sus respectivos intervalos de confianza. Resultados: Verificó relación estadísticamente significante del uso de preservativos con el tipo de escenas que prefiere $(p=$ $0,03)$, preferencia por películas con escenas envolviendo sexo sin protección o mismo aquellos que no se importan cuanto a ese cuidado ( $p=0,02)$, tipo de pornografía que ve influenciando en sus relaciones sexuales $(p=0,017)$ y número de escenas vistas por semana $(p=0,05)$. Conclusiones: El no uso del preservativo fue relacionado al acceso a las escenas eróticas. Descriptores: Sexo; Condones; Personas; Medios Audiovisuales; Conducta Sexual. 


\section{INTRODUCTION}

A new component has brought concern to research regarding the expansion of sexually transmitted infections (STIs), especially HIV/AIDS (the acquired immunodeficiency syndrome). In this context the sexually explicit media (SEM), that is, any type of material that includes the description of genitals or explicit sexual acts of any nature, are capable of stimulating or modifying the viewer's sexual feelings or thoughts ${ }^{(1)}$.

Currently, the access and dissemination of sexually explicit materials in the virtual media has expanded, especially among men, and it is becoming easier due to the advancement of technology ${ }^{(2)}$.

A report from the PornHub website, one of the most visible platforms in the erotic content industry, recorded 81 million visitors per day, with 28.5 million Brazilian visitors in 2017. Brazil was the tenth country that accessed PornHub the most, being considered a nation that has an important rate of consumption of these materials ${ }^{(3)}$.

With the pandemic caused by COVID-19, the use of sites with explicit sexual content has increased $600 \%$, compared to the same period last year. This survey showed that $64 \%$ of professionals started to work remotely; and, with that, a change in the user's behavior occurred $^{(4)}$.

A research carried out in Europe pointed out negative effects perceived regarding the use of pornography, since it can be associated with aggressive sexual behavior ${ }^{(5)}$. In addition, another study, carried out among men who are the sexual partners of other men revealed a positive behavior association between the excessive use of pornography and violence against an intimate partner ${ }^{(6)}$.

Still, a North American study concluded that the consumption of MSEs can present positive aspects, such as understanding desires, learning about sexual identity, stimulating safe sex for the young population, but also negative aspects, such as the naturalization of vaginal and anal sex without condoms, and consequent lead to an increase risk of STIs. This difference can be associated with recent changes in MSEs related to the non-use of condoms in the scenes, especially among men who have sex with men, thus reinforcing the negative influence of these media ${ }^{(7)}$.

Safe sexual practice should be encouraged, including with fixed partners, for the preservation of sexual health ${ }^{(8)}$.Therefore, nursing professionals must provide, as a part of their responsibilities, health education practices, that emphasize the reduction of the population's vulnerability to STIs, addressing the access to sexual media.

Although literature that deals with sexual practices and exposure to HIV/AIDS and other STIs is abundant, studies that address digital media and sexuality are still scarce in Brazil, despite the fact that the consumption of SEMs is expressive in the country.

\section{OBJECTIVE}

To analyze the influence of SEM consumption on condom use.

\section{METHODS}

\section{Ethical aspects}

The research followed the recommendations contained in Resolution 466/12 of the National Health Council, being approved by the Research Ethics Committee of the Federal University of Piauí.

\section{Design, place of study and period}

Cross-sectional study, part of in a bigger project entitled "Influence of the consumption of explicit sexual media on HIV/AIDS risk practices: online survey in the national territory". For greater compliance and transparency of this health research, the EQUATOR instrument, Strengthening the Reporting of Observational Studies in Epidemiology (STROBE) for cross-sectional studies, was used. Data was collected online, from March to September $2020^{(9)}$.

\section{Population and sample: inclusion and exclusion criteria}

The sample consisted of 172 online questionnaires considering participants of both sexes, selected on digital social media. The inclusion criteria were being 18 years or older, living in the state of Piauí and making use of at least one of the digital social networks Facebook', Instagram or WhatsApp。.

\section{Study protocol}

Data collection took place through the social networks Facebook', Instagram ${ }^{\circ}$ and WhatsApp', where the aspects of the research were detailed and an invitation to participate in the study was posted. The participant had access to a link that directed him to the study questionnaire on Google Forms. Those who met the inclusion criteria were included, signed the Free and Informed Consent Form online, and filled out all the items in the questionnaire.

The research instrument was adapted from the study made by Queiroz et al. ${ }^{(10)}$ and, at the end of the questionnaire, there were informative links on the research theme. Sociodemographic variables, vaccination status for hepatitis B, HIV serological status, diagnosis of STIs, use of condoms during sexual intercourse, sexual orientation, and SEM consumption were studied. The outcome variable was "condom use: yes / no". Regarding the consumption of SEM, the participants were asked: if they prefer films involving scenes with the use of condoms or not; whether they agree with the sharing of scenes that present risky behaviors (sex without condoms); how many scenes they usually watch each week (considering that a scene contains, on average, 20 minutes); the main form of access to pornography; whether, in their perception, the consumption of pornography alters the sexual practices; if there is a change in their concept of sex after access to sexual media; and whether sexual media encourages sex without condoms.

\section{Analysis of results and statistics}

Univariate analyses were performed using descriptive statistics with the distribution of frequencies and summary measures. To assess the predictive factors of sexual practice without using condoms, the Poisson regression model was used, with a robust estimator for the covariance matrix. The models were adjusted for each independent variable, and those with a $p$-value less than 0.20 or that are classically associated with the outcome event were included in the multivariate model. A statistically significant difference was considered when the $p$ value was less than 0.05 . Values were expressed in the form of robust prevalence ratio (PR), confidence intervals $(95 \% \mathrm{Cl})$ and significance of the Wald test ( $p$ value). 


\section{RESULTS}

172 participants were evaluated, and over half (51.2\%) consumed SEM. There was a predominance of females (54.1\%), with an average age of 25.7 years, average income equivalent to $R \$ 2,394.4$, with higher education (48.3\%) and who declared to be heterosexual (37.2\%). As for the clinical aspects, the majority reported not having a sexually transmitted infection (STI) (90.7\%). In addition, $0.6 \%$ said they were HIV positive, and $39.5 \%$ were unaware of their HIV status. Regarding vaccination for hepatitis $\mathrm{B}, 18.6 \%$ answered that they do not know or are not vaccinated (Table 1).

Table 1 - Sociodemographic and clinical characteristics of the participants, Teresina, Piauí, Brazil, 2020 ( $N=172)$

\begin{tabular}{|c|c|c|c|c|}
\hline Variables & $\mathbf{n}$ & $\%$ & $\overline{\mathbf{x}}$ & SD \\
\hline \multicolumn{5}{|l|}{ Gender } \\
\hline Female & 93 & 54.1 & & \\
\hline Male & 79 & 45.9 & & \\
\hline Age group (years) & & & 25.7 & 6.3 \\
\hline 18 to 30 & 147 & 85.5 & & \\
\hline 31 to 42 & 22 & 12.8 & & \\
\hline 43 to 59 & 03 & 1.7 & & \\
\hline Income (Brazilian real) & & & $2,394.4$ & $4,285.0$ \\
\hline \multicolumn{5}{|l|}{ Practices a religion } \\
\hline Yes & 115 & 66.9 & & \\
\hline No & 57 & 33.1 & & \\
\hline \multicolumn{5}{|l|}{ Educational level } \\
\hline Post-graduation & 42 & 24.4 & & \\
\hline High school & 47 & 27.3 & & \\
\hline College & 83 & 48.3 & & \\
\hline \multicolumn{5}{|l|}{ Sexual orientation } \\
\hline Bisexual & 19 & 11.0 & & \\
\hline Heterosexual & 64 & 37.2 & & \\
\hline Homosexual & 43 & 25.0 & & \\
\hline Pansexual & 02 & 1.2 & & \\
\hline \multicolumn{5}{|l|}{ Had an STI diagnosis } \\
\hline Yes & 16 & 9.3 & & \\
\hline No & 62 & 90.7 & & \\
\hline \multicolumn{5}{|l|}{ Serological status } \\
\hline HIV positive & 1 & 0.6 & & \\
\hline HIV negative & 103 & 59.9 & & \\
\hline Do not know & 68 & 39.5 & & \\
\hline Vaccinated for hepatitis B & 140 & 81.4 & & \\
\hline No/Do not know & 32 & 18.6 & & \\
\hline \multicolumn{5}{|c|}{ Habit of viewing pornography } \\
\hline Yes & 88 & 51.2 & & \\
\hline No & 84 & 48.8 & & \\
\hline
\end{tabular}

In Table 2, it can be observed that the use of condoms was statistically associated with the age group $(p=0.02)$, preferred pornographic scenes $(p=0.03)$, influence of the types of pornography they watch during sexual practices $(p=0.01)$, being in accordance to the sharing of scenes that involve risky behaviors $(p=0.05)$, and number of scenes they watch weekly $(p=0.05)$.

Six variables met the requirements of the multivariate model and three were associated with unprotected sex. The agreement with sexual scenes involving risky behaviors increases sexual activity without using condoms by 1.49 times. Individuals who prefer scenes involving unprotected sex or even those who do not care about this are 4.24 times more likely to have sexual practices without condoms. The perception of the influence of the type of pornography consumed on sexual relations was associated with a $58.5 \%$ greater chance of unprotected sexual practices (Table 3 ).

Table 2 - Analysis of condom use in sexual practices of consumers of sexually explicit media according to variables of interest, Teresina, Piauí, Brazil, $2020(n=88)$

\begin{tabular}{|c|c|c|c|c|c|}
\hline \multirow{3}{*}{ Variables } & \multicolumn{4}{|c|}{ Condom use } & \multirow{3}{*}{$\boldsymbol{p}$} \\
\hline & \multicolumn{2}{|c|}{ Yes } & \multicolumn{2}{|c|}{ No } & \\
\hline & $\mathbf{n}$ & $\%$ & $\mathbf{n}$ & $\%$ & \\
\hline Gender & & & & & 0.91 \\
\hline Female & 12 & 32.4 & 16 & 31.4 & \\
\hline Male & 25 & 67.6 & 35 & 68.2 & \\
\hline Age group (years) & & & & & 0.02 \\
\hline 18 to 29 & 35 & 94.6 & 40 & 78.4 & \\
\hline 30 to 40 & 2 & 5.4 & 11 & 21.6 & \\
\hline Educational level & & & & & 0.48 \\
\hline Post-graduation & 6 & 16.2 & 12 & 23.5 & \\
\hline College & 21 & 56.8 & 30 & 58.8 & \\
\hline High school & 10 & 27.0 & 09 & 17.7 & \\
\hline Sexual orientation & & & & & 0.72 \\
\hline Heterosexual & 16 & 43.2 & 24 & 47.1 & \\
\hline Homo, bi and pansexual & 21 & 56.8 & 27 & 52.9 & \\
\hline Serological status & & & & & 0.06 \\
\hline HIV positive & 0 & 0.0 & 1 & 2.0 & \\
\hline HIV negative & 16 & 43.2 & 33 & 64.7 & \\
\hline Do not know & 21 & 56.8 & 17 & 33.3 & \\
\hline Type of scenes you prefer & & & & & 0.03 \\
\hline Anything, what matters is the performance & 21 & 56.8 & 36 & 70.6 & \\
\hline When actors do not use condoms & 05 & 13.5 & 13 & 25.5 & \\
\hline When actors use condoms & 11 & 29.7 & 02 & 3.9 & \\
\hline Access to pornography & & & & & 0.89 \\
\hline Free porn sites & 30 & 81.1 & 39 & 76.5 & \\
\hline Paid porn sites and social media & 05 & 13.5 & 10 & 19.6 & \\
\hline Free and paid porn sites & 01 & 2.7 & 01 & 2.0 & \\
\hline Social media & 01 & 2.7 & 01 & 2.0 & \\
\hline $\begin{array}{l}\text { Change in your understanding of sex after } \\
\text { your access to sexual media }\end{array}$ & & & & & 0.36 \\
\hline Yes & 28 & 75.7 & 34 & 66.7 & \\
\hline No & 09 & 24.3 & 17 & 33.3 & \\
\hline $\begin{array}{l}\text { The type of pornography you watch influences } \\
\text { your sexual relationships }\end{array}$ & & & & & 0.02 \\
\hline Yes & 17 & 45.9 & 36 & 70.6 & \\
\hline No & 20 & 54.1 & 15 & 29.4 & \\
\hline Sexual media encourage sex without condoms & & & & & 0.97 \\
\hline Yes & 26 & 70.3 & 36 & 70.6 & \\
\hline No & 11 & 29.7 & 15 & 29.4 & \\
\hline Agrees to scenes that involve risky behavior & & & & & 0.05 \\
\hline Yes & 03 & 8.1 & 12 & 23.5 & \\
\hline No & 34 & 91.9 & 39 & 76.5 & \\
\hline $\begin{array}{l}\text { Number of porn scenes you usually watch per } \\
\text { week }\end{array}$ & & & & & 0.05 \\
\hline Up to two scenes & 20 & 54.1 & 17 & 33.3 & \\
\hline More than two & 17 & 45.9 & 34 & 66.7 & \\
\hline
\end{tabular}

Table 3 - Multivariate model of predictors of sexual practice without using condoms, Teresina, Piauí, Brazil, $2020(n=88)$

\begin{tabular}{lccc}
\hline Variables & $\begin{array}{c}\text { Robust } \\
\text { PR }\end{array}$ & Cl 95\% & $\boldsymbol{p}$ \\
\hline $\begin{array}{l}\text { Agreement with scenes with risky behaviors } \\
\text { Yes }\end{array}$ & $\begin{array}{c}\text { 1.49 } \\
\text { No }\end{array}$ & $1.07-2.08$ & 0.01 \\
$\begin{array}{l}\text { Preference for scene } \\
\text { In which actors do not use condoms/anything }\end{array}$ & $\begin{array}{c}\text { 4.24 } \\
\text { Where actors use condoms }\end{array}$ & $1.17-15.35$ \\
\hline
\end{tabular}


Table 3 (concluded)

\begin{tabular}{|c|c|c|c|}
\hline Variables & $\begin{array}{l}\text { Robust } \\
\text { PR }\end{array}$ & $\mathrm{Cl} 95 \%$ & $p$ \\
\hline Number of porn scenes per week & & & 0.06 \\
\hline More than two & 1.45 & $0.97-2.164$ & \\
\hline Up to two & 1 & & \\
\hline $\begin{array}{l}\text { Influence of the type of pornography in sexual } \\
\text { relations }\end{array}$ & & & 0.03 \\
\hline Yes & 1.58 & $1.03-2.42$ & \\
\hline No & 1 & & \\
\hline
\end{tabular}

Note: $p$ - significance of the Wald test.

\section{DISCUSSION}

The sociodemographic characteristics of the sample in this study are consistent with those found in another research on this topic. It was found that, similarly to other studies, young people seem to consume a greater number of sexually explicit media, which can be explained by the greater affinity of people in this age group with technologies, notably with the use of social networks ${ }^{(11)}$. In addition, young people receive little information about sex education, due to the traditional way and the taboo with which sexuality is viewed, which leads them to resort to the consumption of sexual media as a source of information ${ }^{(12)}$.

As for the access to digital technologies, a study pointed its inequalities ${ }^{(13)}$. Therefore, it is possible to verify that the expansion of the internet and of the use of cellphones and computers may have contributed to the consumption of sexual media, further reinforced by the purchasing power observed in the sample of this study, in which the average income of the participants was higher than Brazilian minimum wage.

The advance of digital technologies allows not only the dissemination of information, but also facilitates communication regarding sexual practices. Thus, the images shared by the digital media are consumed in search of pleasure and as sexual stimuli(14). In general, digital media can be a form of socialization, with the potential to involve the individual in a situation of vulnerability to unprotected sex or drug use, but some research still does not bring this relationship ${ }^{(15)}$.

The findings differed from the literature in regard to sex, since there were more females than males; and, regarding sexual orientation, most were heterosexual. Regarding this variable, a study reports that men are more likely to seek SEM than women ${ }^{(16)}$, and some researchers report that sexually compulsive behaviors, including the excessive use of pornography, are considered an alternative for the male audience to deal with negative situations of affection ${ }^{(17)}$.

In this research, it was identified that consumption characteristics of sexually explicit media are associated with sexual practice without using a condom. Among them, preferring sex scenes without condoms increased the chance of unprotected sex more than four times. This finding can be explained by the social characteristics of the sample, such as the young age group, which is usually associated with unprotected sex. Another aspect that can contribute to this result is related to the possible fragility regarding the knowledge about sexually transmitted infections ${ }^{(8)}$. In addition, the higher concentration in the sample of non-heterosexual population may have been a relevant factor to explain this finding.
Concerning male homosexual relations, a study confirmed the hypothesis that the use of pornography among men is associated with viewing pornography during sex with the partner, causing the partner to reproduce scenes and practices from the pornographic film during sex, as way of obtaining sexual pleasure ${ }^{(18)}$. In this group, the preference for SEM without condoms is classic and similar to what has already been described by other authors, corroborating the existence of a direct link between the preference for "bareback" scenes and the intention of having sex without condoms ${ }^{(19-20)}$.

In the study, it was found that not using condom was statistically associated with being in accordance with sexual scenes that involve risky behaviors, with a preference for films with scenes that involve unprotected sex or those who do not care about this, and the perception of the influence of the type of pornography they consume on their sexual relations. A survey conducted in four cities in the United States found that almost half of the men who have sex with men (MSM) said that watching SEM contributed to their involvement in "riskier sex", with $29 \%$ believing that it contributed to their involvement in the last three months ${ }^{(21)}$. Such findings are consistent with the results of this study.

These attitudes and practices can have several implications. As pornography becomes more widespread and accessible, more people, in relation to previous generations, may be exposed to violent and misogynistic pornographic content ${ }^{(22)}$. Such accessibility and normalization can have implications on the romantic relationships of pornography consumers, in addition to the broader cultural perception of violence towards women.

In addition, a study carried out in 2017 reported that some men filmed sex with their partners without their consent, and some of them used the recording later as a means of gaining control within the post-separation relationship ${ }^{(23)}$.

From another point of view, a research carried out in Paraíba with university students of both genders showed that consumers of sexual media disagree with the idea that pornography brings harmful effects such as addiction, trivialization of sex and, damage to relationships and sexual formation, the opposite perspective of non-consumers, who perceive this consumption as harmful. It was found that the research sample minimized the influence of SEM on their own sexual behaviors ${ }^{(24)}$.

Contrary to these results, a meta-analysis showed an association between the use of pornography and physical and sexual violence ${ }^{(25)}$. Such violence, in turn, triggers psychological and physical problems, including the appearance of injuries and the consequent manifestation of STIs. Thus, prevention and intervention actions against these situations are necessary.

In addition, other research has pointed out that accessing SEM in general is associated with a greater likelihood of engaging in anal sex without condoms ${ }^{(26-27)}$. However, given the lack of studies that have investigated the role of SEM in heterosexual relationships, additional research with a representative sample of SEM consumers is necessary.

It is already proven that the human being has an enormous capacity to imitate behaviors, whether conscious or unconscious. This reproduction of actions is influenced by social, emotional and cognitive factors that translate their preferences, whether directly or indirectly, even if such attitudes or practices constitute some health risk ${ }^{(28)}$. 
On the other hand, a research has suggested that sex without condom becomes just a fetish for consumers of these media. This is because individuals do not perform this practice in reality despite wanting to do so $^{(29)}$.

Most of the sample in this study accesses SEM through websites, and surveys report prevalence rates of viewing ranging from $40 \%$ to $47 \%$. Such data can be explained by technological advances, which enabled expansion and facilitated access to SEM ${ }^{(30)}$.

As for the number of pornographic scenes accessed, most watched up to two a week. Byers et al. ${ }^{(31)}$ reported in their study a significant positive association for hours of internet use per week and use of SEM online, that is, the longer the users stay on the internet, the more they will access SEM. Data shows that $87 \%$ of men reported using pornography at least once a month, with up to $58 \%$ viewing pornography weekly ${ }^{(32)}$.

Some countries are already in alert for the expansion of pornography, the state of Utah in the USA, which received a bill that declares sexually explicit media a "public health crisis". Such decisions can positively impact individuals who consume the media and engage in sex without protection, since the creation of strategies to promote the use of condoms in explicit media can be carried out ${ }^{(33)}$.

Based on these findings, it is of utmost importance to disseminate through the media (a space that concentrates a large part of SEM consumers) educational materials that report STI prevention measures, with a focus on combined HIV prevention, especially vaccination against immunopreventable STIs.

Therefore, knowing the profile of these people is important to understand the dynamic behaviors that involve risk for STIs/ HIV/AIDS, as well as to encourage the publication of new studies on the subject.

\section{Study limitations}

This study has some limitations. Since it is a survey conducted online, it can lead to the misunderstanding of some questions, culminating in participants' mistakes in answers. However, this is mitigated by the fact that literature is full of studies with selfreported data. The small sample size is also a limitation, since the inferential analysis covers a small portion of the population.

It should be noted that, when replicating this study, researchers should consider the cultural differences of the population addressed, both in Brazil and in other countries.

\section{Contributions to the field of Nursing and Public Health}

The increase in the consumption of sexually explicit media can stimulate sex without condoms and lead to an exponential increase in cases of HIV/AIDS, in addition to other sexually transmitted infections. There are still few studies that analyze SEM and the sexual behavior of its users; therefore, this research aims to identify individual vulnerabilities and thus guide health services to investigate the most varied dynamics of HIV infection and other STIs.

For the practice of nursing professionals, this study will contribute with relevant information on the consumption of sexual media and condom use that may assist in strategies and approaches involving the theme of HIV/AIDS and STI prevention during their nursing actions, with more effective services in nursing consultations and health education.

\section{CONCLUSIONS}

The predictors of sexual practice without the use of condoms were: age group corresponding to young adults; condom use or not does not interfere in the preference for the scenes; recognition of the influence of the type of pornography on sexual relations; agreeing with scenes with risky behavior; and watching more than two sexually explicit media scenes a week.

The recognition of vulnerabilities resulting from the consumption of sexual media, especially their influence in reducing the use of condoms, may contribute to the practice of health professionals, with emphasis on the nursing team, which acts directly in the prevention and promotion of health.

\section{ACKNOWLEDGEMENTS}

To the National Council of Scientific and Technological Development, for the PhD scholarship provided to Priscilla Dantas Almeida and the scientific initiation scholarship provided André Felipe de Castro Pereira Chaves. We would also like to thank the Coordenação de Aperfeiçoamento de Pessoal de Nível Superior (the Coordination for the Improvement of Higher Education Personnel) for the MS scholarship provided to Rômulo Veloso Nunes, and to the Universidade Federal do Piauí which bestowed a scientific initiation scholarship to Ellen Cristina da Costa Leite Sousa.

\section{REFERENCES}

1. Hald GM. Gender differences in pornography consumption among young heterosexual Danish adults. Arch Sex Behav [Internet]. 2006[cited 2020 Nov 4];35(5):577-85. Available from: https://link.springer.com/article/10.1007\%2Fs10508-006-9064-0

2. Downing MJ, Schrimshaw EW, Scheinmann R, Antebi-Gruszka N, Hirshfield S. Sexually explicit media use by sexual identity: a comparative analysis of gay, bisexual, and heterosexual men in the United States. Arch Sex Behav [Internet]. 2017[cited 2020 Nov 4];46(6):1763-76. Available from: https://link.springer.com/article/10.1007\%2Fs10508-016-0837-9

3. Canaltech. Pornhub divulga estatísticas de 2017 e mostra que brasileiro adora pornografia[Internet]. 2020 [cited 2020 Nov 4]. Available from: https://canaltech.com.br/comportamento/pornhub-divulga-estatisticas-de-2017-e-mostra-que-brasileiro-adora-pornografia-106304/

4. Techtudo. Acesso a sites pornôs cresce $600 \%$ em período de homeoffice, diz pesquisa[Internet]. 2020 [cited 2020 Nov 5]. Available from: https://www.techtudo.com.br/noticias/2020/08/acesso-a-sites-pornos-cresce-600percent-em-periodo-de-home-office-diz-pesquisa.ghtml 
5. Hald GM, Malamuth NN. Experimental effects of exposure to pornography: the moderating effect of personality and mediating effect of sexual arousal. Arch Sex Behav [Internet]. 2015[cited 2020 Nov 13];44(1):99-109. Available from: https://link.springer.com/article/10.1007\%2 Fs10508-014-0291-5

6. Brem MJ, Garner AR, Grigorian H, Florimbio AR, Wolford-Clevenger C, Shorey RC, et al. Problematic pornography use and physical and sexual intimate partner violence perpetration among men in batterer intervention programs. J Interpers Violence. 2018;21:886260518812806. https://doi.org/10.1177/0886260518812806

7. Nelson KM, Perry NS, Carrey MP. Sexually Explicit Media Use Among 14-17-Year-Old Sexual Minority Males in the U.S. Arch Sex Behav [Internet]. 2019[cited 2020 Nov 20];48(8):234-5. Available from: https://link.springer.com/article/10.1007\%2Fs10508-019-01501-3

8. Spindola T, Oliveira CSR, Santana RSC, Sodré CP, André NLNO, Brochado EJ. Sexual practices, knowledge and behavior of college students regarding sexually transmitted diseases. Rev Pesqui: Cuid Fundam. 2019;11(5):1135-41. https://doi.org/10.9789/2175-5361.2019.v11i5.1135-1141

9. von Elm E, Altman DG, Egger M, Pocock SJ, Gotzsche PC, Vandenbroucke JP. The Strengthening the Reporting of Observational Studies in Epidemiology (STROBE) Statement: guidelines for reporting observational studies [Internet]. 2020[cited 2020 Dec 18]. Available from: https://www.equator-network.org/reporting-guidelines/strobe/.

10. Queiroz AAFLN, Sousa AFL, Brignol S, Araújo TME, Reis RK. Vulnerability to HIV among older men users of dating apps in Brazil. Braz J Infect Dis. 2019;23(5):298-306. https://doi.org/10.1016/j.bjid.2019.07.005

11. Nelson KM, Simoni JM, Morrison DM, George WH, Leickly E, Lengua LJ, et al. Sexually explicit online media and sexual risk among men who have sex with men in the United States. Arch Sex Behav. 2014;43:833-43. https://doi.org/10.1007/s10508-013-0238-2

12. Nelson KM, Pantalone DW, Gamarel KE, Simoni JM. A new measure of the perceived influence of sexually explicit online media on the sexual behaviors of men who have sex with men. J Sex Res. 2016;53(4-5):588-600. https://doi.org/10.1080/00224499.2015.1066744

13. Comitê Gestor da Internet no Brasil. Núcleo de Informação e Coordenação do Ponto BR (Ed.). Desigualdades digitais no espaço urbano: um estudo sobre o acesso e o uso da Internet na cidade de São Paulo [Internet]. São Paulo: 2019[cited 2020 Dec 19]. Available from: https://www. nic.br/publicacao/desigualdades-digitais-no-espaco-urbano-um-estudo-sobre-o-acesso-e-o-uso-da-internet-na-cidade-de-sao-paulo/

14. Melo R. A íntima relação entre as tecnologias comunicativas e nossa experiência afetivo-sexual. Artefactum Rev Estud Ling Tecnol [Internet]. 2016[cited 2020 Dec 19];12(1). Available from: http://artefactum.rafrom.com.br/index.php/artefactum/article/view/996/600.

15. Ferrari W, Nascimento M. Práticas sexuais entre homens em tempos de mídias digitais: perspectivas e desafios ao campo da saúde. Cad Saúde Pública. 2019;35(5). https://doi.org/10.1590/0102-311X00020119

16. O'Reilly S, Knox D, Zusman ME. College student attitudes toward pornography use. Coll Stud J [Internet]. 2007[cited 2020 Dec 7];41(2):402-6. Available from: https://eric.ed.gov/?id=EJ777947

17. Brem MJ, Shorey RC, Anderson S, Stuart GL. Depression, anxiety, and compulsive sexual behavior among men in residential treatment for substance use disorders: the role of experiential avoidance. Clin Psychol Psychother. 2017;24:1246-53. https://doi.org/10.1002/cpp.2085

18. Sun C, Bridges A, Johnson JA, Ezzell MB. Pornography and the male sexual script: an analysis of consumption and sexual relations. Arch Sex Behav. 2016;45:983-94. https://doi.org/10.1007/s10508-014-0391-2

19. Thai M, Barlow FK. Bareback sexually explicit media consumption and men who have sex with men's responses to sexual partners who prefer anal intercourse with or without condoms. Arch Sex Behav [Internet]. 2019[cited 2020 Dec 18];48(4):1191-1201. Available from: https://link.springer.com/article/10.1007\%2Fs10508-018-1182-y

20. Martins AA, Queiroz AAFLN, Frota OP, Araújo TME, Mendes IAC, Fronteira I, et al. Consumo de mídias sexualmente explícitas e sexo anal desprotegido em homens que fazem sexo com homens. Cienc Saude Colet [Internet]. 2020 [cited 2021 Feb 21]. Available from: http://www.cienciaesaudecoletiva.com.br/artigos/ consumo-de-midias-sexualmente-explicitas-e-sexo-anal-desprotegido-em-homens-que-fazem-sexo-com-homens/17796

21. Schirmshaw EW, Antebi-Gruszka N, Downing Jr MJ. Viewing of Internet-based sexually explicit media as a risk factor for condom less anal sex among men who have sex with men in four U.S. PLoS One. 2016;11(4):1-11. https://doi.org/10.1371/journal.pone.0154439

22. Price J, Patterson R, Regnerus $M$, Walley J. How much more XXX is generation X consuming? evidence of changing attitudes and behaviors related to pornography since 1973. J Sex Res. 2016;53(1):12-20. https://doi.org/10.1080/00224499.2014.1003773

23. DeKeseredy WS, Hall-Sanchez A. Adult pornography and violence against women in the heartland: results from a rural southeast Ohio study. Viol Against Women. 2017;23:830-49. https://doi.org/10.1177/1077801216648795

24. Guerra VM, Andrade FCB, Dias MR. Atitudes de estudantes universitários frente ao consumo de materiais pornográficos. Estud Psicol. 2004;9(2):269-77. https://doi.org/10.1590/S1413-294X2004000200008

25. Wright PJ, Tokunaga RS, Kraus A. A meta-analysis of pornography consumption and actual acts of sexual aggression in general population studies. J Communic. 2016;66:183-205. https://doi.org/10.1111/jcom.12201

26. Eaton LA, Cain ND, Pope H, Garcia J, Cherry C. The relationship between pornography use and sexual behaviors among at-risk HIV-negative men who have sex with men. Sexual Health [Internet]. 2012[cited 2020 Dec 21];9:166-70. Available from: https://www.ncbi.nlm.nih.gov/ pmc/articles/PMC3560402/

27. Stein D, Silveira R, Hagerty R, Marmor M. Viewing pornography depicting unprotected anal intercourse: are there implications for HIV prevention among men who have sex with men? Arch Sex Behav [Internet]. 2012[cited 2020 Dec 21];41:411-9. Available from: https://link. springer.com/article/10.1007\%2Fs10508-011-9789-2 
28. Chartrand TL, Lakin JL. The antecedents and consequences of human behavior al mimicry. Ann Rev Psychol. 2013;64:285-308. https://doi. org/10.1146/annurev-psych-113011-143754

29. Nelson KM, Eaton LA, Gamarel KE. Preferences for condomless sex in sexually explicit media among Black/African American men who have sex with men: implications for hiv prevention. Arch Sex Behav. 2017;46(4):977-85. https://doi.org/10.1007/s10508-016-0878-0

30. Selwyn N. A safe haven for misbehaving? an investigation of online mis behavior among university students. Soc Sci Comput Rev. 2008;26(4):446-65. https://doi.org/10.1177/0894439307313515

31. Byers LJ, Menzies, KS, O'Grady WL. The impact of computer variable son the viewing and sending of sexually explicit material on the Internet: testing Cooper's 'Triple-A Engine'. Can J Hum Sex [Internet]. 2004[cited 2021 Jan 5];13(3-4): 157-170. Available from: https://www. researchgate.net/publication/285809232_The_impact_of_computer_variables_on_the_viewing_and_sending_of_sexually_explicit_ material_on_the_Internet_Testing_Cooper\%27s_Triple-A_Engine

32. Regnerus M, Gordon D, Price J. Documenting pornography use in America: a comparative analysis of methodological approaches. J Sex Res. 2016;53:873-81. https://doi.org/10.1080/00224499.2015.1096886

33. Utah State Legislature. Senate Concurrent Resolution (S.C.R.9). Concurrent Resolution on the Public Health Crisis of Pornography [Internet]. 2016 [cited 2021 Jan 5]. Available from: https://utahcoalition.org/scr9-resolution-public-health-crisis-pornography/ 